\title{
ECOLOGIZATION OF INNOVATIVE DEVELOPMENT OF REGIONS ON THE PRINCIPLES OF GLOCALIZATION
}

\author{
**Olena Hetman ${ }^{1}$, Olga Iermakova ${ }^{2}$, Oleksandr Laiko ${ }^{3}$, Oksana Nikishyna $^{4}$ \\ ${ }^{1}$ PhD in Economics. Institute of Market Problems and Economic\&Ecological Research of \\ the National Academy of Sciences of Ukraine, Frantsuz'kyy bul'var, 29, 65000, Odessa, Ukraine. \\ Phone +380972624296. E-mail helenagetman24@gmail.com \\ ${ }^{2}$ Assoc. Prof. Dr. Institute of Market Problems and Economic \&Ecological Research of the \\ National Academy of Sciences of Ukraine, Odessa, Ukraine. E-mail impeer@ukr.net \\ ${ }^{3}$ Senior researcher. Dr. Institute of Market Problems and Economic \&Ecological Research \\ of the National Academy of Sciences of Ukraine, Odessa, Ukraine.E-mail alexlayko@ gmail.com \\ ${ }^{4}$ Senior researcher. Dr. Institute of Market Problems and Economic\&Ecological Research \\ of the National Academy of Sciences of Ukraine, Odessa, Ukraine.E-mail ksenkych@ gmail.com
}

Received 1108 2019; Accepted 20092019

The success of the country's economic policy depends on successful combination of the global world trends and national / regional peculiarities of economic development. The implementation of the principles of glocalization to the regional innovation policy is able to overcome the limited local approach and negative global manifestations, thus creating a unique, globally competitive innovative product. In the innovation sphere, processes of glocalization manifest themselves in the complementarity of local factors of innovative development, in particular, the unique innovation environment, human and social capital, with global factors of innovative development. The aim of this work is to explore scientific approaches to ecologization of innovation development, which will determine the direction, peculiarities and nature of the processes of glocalization, and will be their modern accelerator. The research methodology is systematization of approaches to the direction of innovation processes for the development, creation and implementation of innovations in the form of new products, technology, method, form of production organization, etc., which directly or indirectly contributes to reducing the environmentally destructive effects of production and consumption on the environment and solving environmental problems. Results of the research. The final result of ecologization of innovation activity in the region is a positive socio-ecological and economic effect, which ensures balanced sustainable development of the region and the state as a whole. Thus, the modern accelerator of the glocalization of economic processes is the ecologization of innovation development, in the nature of which there are incentives for self-development, reproduction, generation of innovative ideas, production of new technologies, goods and services, ensuring the balancing of the socio-ecological and economic potential of the region and the country as a whole, which determines the direction, peculiarities and nature of the processes of glocalization.

Key words: ecologization of innovative development, glocalization.

JEL Codes: O10, Q50.

Copyright (C) 2019 The Authors. Published by Vytautas Magnus University. This is an open-access article distributed under the terms of the Creative Commons Attribution-NonCommercial 4.0 (CC BY-NC 4.0) license, which permits unrestricted use, distribution, and reproduction in any medium, provided the original author and source are credited. The material cannot be used for commercial purposes. 


\section{Ecologization of the Innovative Development of Regions on the Principles of Glocalization. Olena Hetman, Olga Iermakova, Oleksandr Laiko, Oksana Nikisyna}

\section{Introduction}

Creation of innovative economics with preservation of principles of a sustainable development and environment protection is a demand of a current policy of the world countries and it presents important challenges to Ukraine. They relate to a constant economic growth and involve a reasonable usage of ecological resources and adhering to human rights.

Strengthening of regions' economy, creation of their competitive priority based on innovations as well as capability to cooperate with the state and private structures working in the region, involvement of the population to an innovative process is a direction of a current development policy of the European Union determined in a new economic EU strategy "Europe 2030".

The etymology of the word "innovation" comes from the Latin word "innovare" - to renew, change. Schumpeter first introduced this term into a scientific vocabulary which when translated literally means "implementing of a scientific discovery or technical invention into a new technology or a new type of product". Besides, the innovation was considered by Schumpeter (2007) as a new function of production, its new combination. The third edition of Oslo Manual (2005) determines innovations as the implementation of a new or significantly improved product (goods or service), or process, a new marketing method, or a new organisational method in business practices, workplace organization or external relations.

The definition of the "innovation" term at the state level is provided by the Law of Ukraine "On Innovative Activities"(2002), where the innovation is determined as a newly-created (implemented) and improved competitive technologies, goods or services as well as organizational and technical solutions - productive, administrative, commercial and others, improving significantly a production structure and quality and (or) social sphere. According to the broad definition by Yakovets (2011) the innovation is an introduction of new elements (types or methods) into human activities which increase an outcome of these activities. The essence of innovations in a market economy is creation of a new value for a consumer (Gusev, 2011).

In this research we will be focused on a regional level of an innovative policy. According to an economic approach the region is a primary type of a relatively separate territorial organisation of business activities of the population which is to provide a reproductive integrity of the activities, which may be a self-supportive one, as well as an interrelation with an external economic environment (economic systems of a similar or higher level - other regions, countries, etc.). According to the most common definition of the "region" notion complying with a conceptual framework of the state policy and administrative law applied in the countries of the European Union, the region is considered as an administrative and territorial unit of a sub-national level which is immediately subordinate to the central government authority, has its elective and executive power, individual budget and is legally capable to act (Yakovets, 2011). 
The support of innovations on the regional level is on agenda in the development of national and global innovation processes. An influence of innovations on the economic development of countries and regions is theoretically and practically proved today. In particular, in the research of the Organisation for Economic Co-operation and Development (OECD) "Regions and Innovative Policy" (2011). The conclusion on existence of a linear relationship between a long-term economic development and a policy in the domain of science, technologies and innovations was obtained based on the analysis of the innovative development of regions of the leading world countries.

The development is considered as progressive changes in the economic sphere. If the change is quantitative, this is an economic growth. The qualitative change provides for the structure changes as follows: either changes in the contents of the development or obtaining of new characteristics by the economic system (Kupalova, G., 2008, p. 92-93). P. Samuelson stated that it is impossible to aim for only a qualitative growth of the production, a domestic development of the whole social and economic structure of the society is also necessary. The development always has a direction defined by a purpose or a system of purposes. If the direction of the development is positive, this means a progress, if it is negative, this means a regress or degradation (Kupalova, 2008).

The purpose of the innovative policy is determined by the Law of Ukraine "On Innovative Activities" (2002) as a provision of a sustainable development and improving of the quality of the social life.

As specified by the OECD research (2015), the economic growth which is measured by the GDP (gross domestic product), cannot be a priority task of the state policy any more as well as it cannot be a final itself. The countries' governments pay more and more attention to the all-embracing growth aiming to improve living standards and distribute the advantages of the social welfare among the social groups more equally. It is also determined that differences in other results not related to an income, including obtaining of education, state of health and possibilities for employment, affect not only the welfare but also the growth.

Thousands of years established in the World Summit for Sustainable Development in Johannesburg underline the necessity of integration of environmental aims in the development policy. The process of greening the economy is considered in numerous spheres and embraces a number of issues such as the development of clean technologies (Bönte, W., Dienes, Ch. 2013), renewable energy sources, increasing of power and material effectiveness, changing of a consuming model and production of a more sustainable, integrated policy related to the products, green public purchases, green working places and an ecological fiscal reform (Ryszko, 2016; Sharma, Vredenburg, 1998).

The scientific association is nowadays more and more concerned at the concept "circular economy" (2019) which has a chain at the core "take, make, reuse". The "circular economy" is defined by the specialists as the economy peculiar to a renewable and closed nature. Its basis is made by closed supply chains, which are understood as stages providing maximisation of the added value during the whole product life circle 


\section{Ecologization of the Innovative Development of Regions on the Principles of Glocalization. Olena Hetman, Olga Iermakova, Oleksandr Laiko, Oksana Nikisyna}

with a dynamic renewing within durable temporary intervals of values of different types and scopes.

The term "inclusive economic growth" began to be applied actively by the specialists being stipulated in a number of significant international documents. Certain scientific sources focus on a social component of this term, underlining that an inclusive growth provides for a broad involvement of the population to the production process and promotes more fair distribution of its results among different population strata. For this reason the ecologization of innovative development must be based on a phased transition to the model "circular economy" with its further transformation into an allembracing model of the "inclusive economy".

As the main priority objectives of ecologization of innovative development, there are considered most often the goals related to the changes in socio-economic development of the economic system, which, along with the positive socio-economic effect, improve the state of the environment or significantly minimize the negative impact on it. Therefore, under the ecologization of innovative development of the regions, reference is made to the innovative processes for the development, creation and implementation of innovations in the form of new products, technology, method, form of production organization, etc., which directly or indirectly assist to minimize the negative impact of production and consumption on the environment and dealing with the ecological problems (Hetman, 2019b, Iermakova, 2017).

Ecologization of the innovative development of the region is a complex process, in which certain tasks need to be addressed (Iermakova, Laiko, Hetman, Nikishyna, Tsynalievska, 2019):

- formation of the concept of environmentalization of socioeconomic development;

- development of the system of organization and financing of ecologization of innovative development of the region;

- legal regulation at the international, state, regional and local levels;

- harmonization of socio-economic and biotechnological decisions.

We propose to consider processes of ecologization of innovative development of the region as a catalyst for the processes of market glocalization, which will promote sustainable development of the regional economy. The aim of this work is to explore scientific approaches to ecologization of innovation development, which will determine the direction, peculiarities and nature of the processes of glocalization, and will be their modern accelerator.

\section{Methods}

The research methodology is systematization of approaches to the direction of innovation processes for the development, creation and implementation of innovations in the form of new products, technology, method, form of production organization, 
etc., which directly or indirectly contributes to reducing the environmentally destructive effects of production and consumption on the environment and solving environmental problems.

\section{Results and Discussions}

Ecologization of innovative development of the region is a systemic dynamic process of creation, implementation and dissemination in the region as environmentally oriented innovations so as raising the level of environmental friendliness of innovations, penetration of the environmental world view into all areas of economic activity of the region, inclusion of the environmental component in the system of financial and economic relations, formation of environmental infrastructure and education (Institutional principles, 2017).

The result of ecologization of innovative activity in the region is a positive socioecological and economic effect, which ensures balanced sustainable development of the region and the state as a whole. Thus, the modern accelerator of the glocalization of economic processes is the ecologization of innovation development, in the nature of which there are incentives for self-development, reproduction, generation of innovative ideas, production of new technologies, goods and services, ensuring the balancing of the socio-ecological and economic potential of the region and the country as a whole, which determines the direction, the peculiarities and nature of the processes of glocalization.

Integration of regional socio-ecological and economic systems into national and global networks is possible by facilitating access to them and creating opportunities for their use by appropriate institutional support and financial incentives. The development of modern economic systems is characterized by two opposing trends: globalization and localization of markets. The result of their interaction and synthesis is the process of market-based glocalization, which is one of the characteristics of the post-industrial economy.

The initial stage of market glocalization is the expansion of product market boundaries by the emergence of production of innovative products with specific properties that are in demand not only on local but also global markets. The next step is the export of these products, which, on the one hand, helps to establish and strengthen the integrative links between the local and global markets, the interpenetration of the local market in the world market space, on the other hand, leads to the expansion of the geographical boundaries of the market, that is, its glocalization.

The characteristic features of internal glocalization (using the example of agrofood markets of the Odessa region) include the following:

1) expansion of the boundaries of the local market through adjacent areas, its flexibility, openness and interregional character;

2) strengthening the role and stabilizing function of the Odessa region in the development of the agro-food complex in the Black Sea region, which slows down the pace of reduction of production volumes with high added value. 


\section{Ecologization of the Innovative Development of Regions on the Principles of Glocalization. Olena Hetman, Olga Iermakova, Oleksandr Laiko, Oksana Nikisyna}

On the basis of empirical studies (Nikishina, Zarudna, 2018, Nikishina, Bibikova, 2018), we will present the following to the characteristic trends of the external glocalization of the agricultural market of the Odessa region:

1) the expansion of product market boundaries due to the emergence of innovative long-term storage products and their export and, as a consequence, the expansion of the geographical boundaries of the local market, its integration into the world market space;

2) the significant transformational impact of structural changes in world trade on the export of domestic processed products;

3) the dominant raw material orientation of domestic agricultural exports and the ineffective use of the powerful potential (resource, innovation, labor) of the agrofood complex of Ukraine and its regions.

In the conditions of the stagnation of global demand for commodities, the state faces the task of modernizing market policy in the internal and external dimensions in order to maximize theuse of benefits of glocalization while simultaneously minimizing its negative effects. It is expedient to shift the emphasis of internal market policy in support of regional producers of quality and environmentally safe processed products, to assist them in certification for export to the EU and other countries of potentially competitive goods. It is expedient to direct the vector of the foreign market policy of the state on implementation of export potential of high value-added goods markets by strengthening the position of exporters in the traditional and development of new external markets.

The author hypothesis is that the glocalization of commodity markets on the basis of the implementation of environmental innovations will contribute to the sustainable development of the economy of the regions. We propose to consider environmental innovations as a catalyst for the processes of market glocalization in the internal and external dimensions. In the conditions of implementation of the principles of sustainable and balanced development of national economies, the environmental component of market glocalization becomes of paramount importance, determining the direction, peculiarities and nature of glocalizational processes. Further expansion of commodity and territorial boundaries of local markets will be possible due to the active implementation of environmental innovations by market actors focused on the formation of closed reproductive cycles, the development and production of new environmentally friendly goods, the use of resource-saving and low-waste technologies, new organizational forms, etc. Environmental innovations can intensify and transform the processes of market-based glocalization, harmonize its socio-economic and environmental guidelines, change the type of market (for example, from local to regional or state), price and quality parameters of the product, characteristics of supply and demand, and significantly expand the markets.

Also, environmental innovations can increase the competitiveness of commodity producers through the reduction of their costs by saving resources, giving them the advantage of expanding the territorial boundaries of the market, entering into global value-added chains, etc. Thus, the implementation of environmental management and 
marketing systems, environmental technologies, that ensure the interaction between economic growth and protection of the natural environment, will contribute to the establishment of an environmentally-oriented type of market-based glocalization processes for the sustainable development of systems of different levels.

The environmental factor in ensuring the competitiveness of both economic entities and domestic commodity markets is becoming increasingly important and receives financial support. In Ukraine, in 2017, the volume of capital investments in environmental protection amounted to 11.03 billion $\mathrm{UAH}$, having increased four times as compared to 2010 (Table 1).

Table 1. Dynamic and structural changes in capital investment in environmental protection in some regions of Ukraine, UAH million

\begin{tabular}{|l|c|c|c|c|c|c|c|}
\hline \multirow{2}{*}{\multicolumn{1}{c|}{ Regions }} & \multicolumn{2}{|c|}{2010} & \multirow{2}{*}{2014} & 2015 & 2016 & \multicolumn{2}{c|}{2017} \\
\cline { 2 - 6 } \cline { 7 - 9 } & $\begin{array}{c}\text { UAH } \\
\text { mln. }\end{array}$ & $\%$ & & & $\begin{array}{c}\text { UAH } \\
\text { mln. }\end{array}$ & $\%$ \\
\hline Ukraine, total, incl. regions & $\mathbf{2 7 6 1 , 5}$ & $\mathbf{1 0 0 , 0}$ & $\mathbf{7 9 5 9 , 9}$ & $\mathbf{7 6 7 5 , 6}$ & $\mathbf{1 3 3 9 0 , 5}$ & $\mathbf{1 1 0 2 5 , 6}$ & $\mathbf{1 0 0 , 0}$ \\
\hline Kiev & 101,1 & 3,7 & 4287,6 & 4648,5 & 9021,4 & 5023,7 & 45,6 \\
\hline Dnipropetrovsk & 950,9 & 34,4 & 1505,2 & 1417,9 & 1662,3 & 2628,8 & 23,8 \\
\hline Donetsk & 575,0 & 20,8 & 374,7 & 232,3 & 650,9 & 774,6 & 7,0 \\
\hline Zaporozhe & 159,3 & 5,8 & 881,3 & 591,5 & 1062,8 & 817,1 & 7,4 \\
\hline Kharkov & 98,6 & 3,6 & 69,6 & 62,9 & 95,2 & 340,7 & 3,1 \\
\hline Ivano-Frankivsk & 136,9 & 5,0 & 139,7 & 90,5 & 119,7 & 370,4 & 3,4 \\
\hline Mykolaiv & 31,3 & 1,1 & 51,8 & 98,2 & 122,7 & 118,1 & 1,1 \\
\hline Odessa & 55,4 & 2,0 & 9,8 & 26,5 & 17,5 & 95,1 & 0,9 \\
\hline Kherson & 2,8 & 0,1 & 6,7 & 7,9 & 2,3 & 3,2 & 0,03 \\
\hline Black Sea region total & $\mathbf{8 9 , 5}$ & $\mathbf{3 , 2}$ & $\mathbf{6 8 , 3}$ & $\mathbf{1 3 2 , 6}$ & $\mathbf{1 4 2 , 5}$ & $\mathbf{2 1 6 , 4}$ & $\mathbf{2 , 0}$ \\
\hline
\end{tabular}

Note: calculated by the authors according to the data of the State Statistics Service of Ukraine (2018), Prokopenko, O. M. (Eds.), 2018.

In the regional dimension, the largest share of environmental investments is in Kyiv (45.6\% in 2017), Dnipropetrovsk (23.8\%) and Zaporozhe (7.4\%) regions. For 2010-2017, the share of the Black Sea region in the structure of total capital environmental investments decreased from $3.2 \%$ to $2.0 \%$, which is evidence of a rather weak financial basis for the implementation of environmental innovations. The highest growth rate of capital investment is characteristic of the Kiev region, the share of which increased from $3.7 \%$ in 2010 to $45.6 \%$ in 2017 (see Table 1).

Along with capital economic entities, current environmental protection costs, which have a growing trend, are carried out (Table 2). Thus, in 2017, the current environmental costs in Ukraine amounted to 20.47 billion UAH, which is twice the level in 2010 and 1.9 times higher than the volume of capital environmental investments. In the regional dimension, the largest share of current costs is in Dnipropetrovsk (27\% in 2017), Kiev (15.1\%) and Zaporozhe (9.8\%) regions. The share of the Black Sea region in the structure of state environmental costs reached $11.3 \%$ in 2017 and has a slowly growing trend (see Table 2). 
Ecologization of the Innovative Development of Regions on the Principles of Glocalization. Olena Hetman, Olga Iermakova, Oleksandr Laiko, Oksana Nikisyna

Table 2. Dynamic and structural changes in current costs on environmental protection in some regions of Ukraine, UAH million

\begin{tabular}{|l|c|c|c|c|c|c|c|}
\hline \multirow{2}{*}{ Regions } & \multicolumn{2}{|c|}{2010} & \multirow{2}{*}{2014} & 2015 & \multirow{2}{*}{2016} & \multicolumn{2}{c|}{2017} \\
\cline { 2 - 5 } \cline { 7 - 8 } & $\begin{array}{c}\text { UAH } \\
\text { mln. }\end{array}$ & $\%$ & & & & $\begin{array}{c}\text { UAH } \\
\text { mln. }\end{array}$ & $\%$ \\
\hline Ukraine, total, incl. regions & $\begin{array}{c}\mathbf{1 0 3 6 6 ,} \\
\mathbf{6}\end{array}$ & $\mathbf{1 0 0 , 0}$ & $\mathbf{1 3 9 6 5 , 7}$ & $\mathbf{1 6 9 1 5 , 5}$ & $\mathbf{1 9 0 9 8 , 2}$ & $\mathbf{2 0 4 6 6 , 4}$ & $\mathbf{1 0 0 , 0}$ \\
\hline Kiev & 676 & 6,5 & 1686 & 1972,5 & 2801,8 & 3089,8 & 15,1 \\
\hline Dnipropetrovsk & 2432,4 & 23,5 & 5069,9 & 5494,3 & 5481,7 & 5533,5 & 27,0 \\
\hline Donetsk & 1625,2 & 15,7 & 1149,4 & 1431,5 & 2054,5 & 1852,6 & 9,1 \\
\hline Zaporozhe & 766,3 & 7,4 & 1274,7 & 1587,1 & 1849,6 & 2003 & 9,8 \\
\hline Kharkov & 526,9 & 5,1 & 635,5 & 787,8 & 822,4 & 900 & 4,4 \\
\hline Ivano-Frankivsk & 148,4 & 1,4 & 186,7 & 234 & 252,7 & 316,2 & 1,5 \\
\hline Mykolaiv & 546,7 & 5,3 & 748,3 & 1502,5 & 1358,8 & 1446,7 & 7,1 \\
\hline Odessa & 332,8 & 3,2 & 208,3 & 279,3 & 519,7 & 778,4 & 3,8 \\
\hline Kherson & 60,5 & 0,6 & 62,8 & 71,7 & 74 & 78,1 & 0,4 \\
\hline Black Sea region total & $\mathbf{9 4 0}$ & $\mathbf{9 , 1}$ & $\mathbf{1 0 1 9 , 4}$ & $\mathbf{1 8 5 3 , 5}$ & $\mathbf{1 9 5 2 , 5}$ & $\mathbf{2 3 0 3 , 2}$ & $\mathbf{1 1 , 3}$ \\
\hline
\end{tabular}

Note: calculated by the authors according to the data of the State Statistics Service of Ukraine (2018), Prokopenko, O. M. (Eds.), 2018.

In Ukraine, in the structure of total costs on environmental protection the current costs are dominated $-65 \%$ in 2017, the share of capital investment accounted for $35 \%$ (Table 3). In the structure of state capital investments $57.2 \%$ of their volume is directed to cleaning and $39.1 \%$ - in integrated technologies.

Table 3. The structure of capital investment in environmental protection in some regions of Ukraine in 2017,\%

\begin{tabular}{|c|c|c|c|c|c|c|}
\hline \multirow{3}{*}{ Regions } & \multirow{2}{*}{\multicolumn{2}{|c|}{$\begin{array}{l}\text { Costs for protection of } \\
\text { the environment, total }\end{array}$}} & \multicolumn{4}{|c|}{ Incl. capital investments: } \\
\hline & & & \multicolumn{2}{|c|}{ in cleaning } & \multicolumn{2}{|c|}{ in integrated technology } \\
\hline & UAH mln. & $\%$ & $\begin{array}{l}\text { UAH } \\
\text { mln. }\end{array}$ & $\%$ & UAH mln. & $\%$ \\
\hline Ukraine, total, incl. regions & 31492,0 & 100,0 & 6305,0 & 100,0 & 4313,3 & 100,0 \\
\hline Kiev & 8113,5 & 25,8 & 2023,2 & 32,1 & 2974,6 & 69,0 \\
\hline Dnipropetrovsk & 8162,3 & 25,9 & 2043,4 & 32,4 & 577,3 & 13,4 \\
\hline Donetsk & 2627,2 & 8,3 & 701,6 & 11,1 & 72,9 & 1,7 \\
\hline Zaporozhe & 2820,1 & 9,0 & 446,3 & 7,1 & 193,6 & 4,5 \\
\hline Kharkov & 1240,8 & 3,9 & 102,6 & 1,6 & 94,6 & 2,2 \\
\hline Ivano-Frankivsk & 686,6 & 2,2 & 289,3 & 4,6 & 76,1 & 1,8 \\
\hline Mykolaiv & 1564,8 & 5,0 & 114,1 & 1,8 & 1,1 & 0,03 \\
\hline Odessa & 873,5 & 2,8 & 86,6 & 1,4 & 8,2 & 0,2 \\
\hline Kherson & 81,3 & 0,3 & 2,6 & 0 & 0 & 0 \\
\hline Black Sea region total & 2519,6 & 8,0 & 203,3 & 3,2 & 9,3 & 0,2 \\
\hline
\end{tabular}

Note: calculated by the authors according to the data of the State Statistics Service of Ukraine (2018), Prokopenko, O. M. (Eds.),2018. 
In 2017, the volume of environmental investments invested in integrated technologies in Ukraine amounted to UAH 4.31 billion, 69\% of which were implemented in Kyiv region $13.4 \%$ and $4.5 \%$ in Dnipropetrovsk and Zaporozhe regions respectively.

These regions are leaders in implementing environmental innovations in Ukraine. In the Black Sea region, the volume of environmental investment in integrated technology amounted to only 9.3 million $\operatorname{UAH}(0,2 \%)$, which is an indication of the unused potential of innovative development ecologization.

In the sectoral dimension in $2017,44 \%$ of the capital environmental investment in the state accounted for electricity, gas, steam and air-conditioning sector, $23.1 \%$ for the processing industry and $13.3 \%$ for the extractive industry. During the period 2014$2017 \mathrm{gg}$. there have been structural changes in the direction of reducing the share of electricity supply sector and processing industry in parallel with the growth of the extractive industry, water, public administration and defense sectors. Despite the growing trend, the share of agriculture in capital environmental investments is still insignificant $(0.5 \%)$, which reduces the agrarian sector's ability to implement environmental innovations.

Thus, the analysis of environmental investment trends in Ukraine has demonstrated a growing trend in the cost of environmental protection, domination in their current cost structure, direction of about $40 \%$ of capital investment in integrated technology. Leading regions in the implementation of environmental innovations are Kiev, Dnipropetrovsk and Zaporozhe regions. Subjects of these areas increase the competitiveness of products at the expense of the environmental component, expanding the product and territorial boundaries of local markets through the development and implementation of environmental innovations. The Black Sea region remains an outsider on the level of environmental investments, has untapped potential of market-based glocalization due to the environmental component. Also, the low level of environmental investment is inherent in the agro-food sector of Ukraine, which reduces its financial base for the implementation of environmental innovations, expansion of product boundaries of strategic markets and their integration into global value-added chains.

In ecologization of innovative development there is a major problem related to the situation when manufacturers are ready to use the public goods (clean air and clean water), but are not ready to invest in innovations: in construction of treatment facilities, implementation of modern resource-saving, including energy-saving technologies, etc. The solution of such a problem is possible through state regulation, that is, through the system of measures, by which the state influences socio-ecological and economic development: implementation of a system of measures for the legal provision of ecologization of innovative development (development and adoption of laws on technology transfer, formation and regulation of the market of venture capital); development of a system of incentives and mechanisms for the wide practical use of results; implementation of mechanisms for the continuous monitoring of ecologically oriented innovation activity, assessment of innovations and their rating, assessment of the efficiency of using public funds by participants of ecologically oriented innovation processes; development of a network of regional information and consulting centers to promote 


\section{Ecologization of the Innovative Development of Regions on the Principles of Glocalization. Olena Hetman, Olga Iermakova, Oleksandr Laiko, Oksana Nikisyna}

the implementation of ecologically oriented innovative products and technologies; creation of a centralized computer databank to provide information on the latest technologies and high-tech products; development and implementation of educational programs of innovative management and modern technologies; measures to promote environmental innovative development, aimed at raising the level of ecologically oriented innovative culture of employees of the authorities and population, presenting in the media explanations and lack of alternatives of ecologically oriented innovative development for the country; development of the infrastructure of the ecologically oriented structure of innovation activity, innovative centers of consulting, engineering, advertising, marketing, audit firms.

Formation of ecologization of innovative development requires the development of a clear strategy and purposefulness of implementation of measures at the regional level and should include mobilization of investment resources and determination of directions of their most effective and rational use in the interests of the population of the region and individual investors. Innovative ecologically oriented development is very important in the development of the region, as it is aimed at overcoming the environmental crisis, and allows solving specific environmental problems.

\section{Conclusion}

Scientific novelty of the research is to develop the theoretical principles of the glocalization of economic processes by substantiating the role of environmental innovations as a catalyst for modern processes of market glocalization (internal and external),capable of transforming the nature, parameters and direction of the glocalization of commodity markets, harmonizing its socio-economic and environmental targets, and intensifying the processes of the environmentally oriented type of glocalization in order to ensure sustainable balanced development of the economy of the state and its regions.

\section{Acknowledgements}

The publication was prepared within the framework of the scientific project "Development of Strategies of Innovative Development for the Regions of Ukraine on the Principles of Glocalization (by the Example of the Odessa Region)" at the expense of the budget program "Support of the development of priority areas of scientific research" (КПКВК 6541230)

\section{References}

Bönte, W., Dienes, Ch. (2013), Environmental Innovations and Strategies for the Development of New Production Technologies // Empirical Evidence from Europe, "Business Strategy and the Environment Bus. Strat. Env." No. 22, p. 501-516

Circular Economy Strategy. (2019). Environment Directorate-General of the European Commission website -http://ec.europa.eu/environment/circular-economy/index_en.htm [10 06 2019]. 
EIO Europe in transition. (2013). Paving the way to a green economy through eco-innovation // Eco-innovation. Observatory Founded by the European commission, Brussels

Freeman, Ch. (1982), Economics of Industrial Innovation, London

Gusev, V. (2011). State innovation policy: methodology of formation and implementation: monograph // Donetsk: Southeast. 624 p.

Hetman, O. L. (2019a). Ecology of the innovative development of the regions // Collection of scientific articles on the materials of the V All-Ukrainian scientific-practical conference on international participation (pp.16-19). Dnepr: NMetAU.

Hetman, O. L. (2019b). Mechanisms of ecologization management of innovation and technological development. Management of innovative development at macro, meso and macro levels: Collection of scientific articles on materials of the $\mathrm{V}$ international scientific and practical Internet conference (pp. 29-31). Odessa: Odessa National Polytechnic University. - https://economics.opu.ua/files/science/innov_roz/2019/tezy.pdf [10 06 2019]

Iermakova, O. A. (2017). Institutional levers to improve Ukraine's regional innovation policy in the context of global challenges // Odesa: IMPEER NASU. $394 \mathrm{p}$.

Iermakova, O. A., Laiko, O. I., Hetman, O. L., Nikishyna, O. V, Tsynalievska, I. A. (2019). Methodical Toolkit of Strategizing of Innovative Development of Regions on the Principles of Glocalization of Economic Processes // Odesa: IMPEER NASU. 55 p.

Institutional principles of ecologization of development of sectors of the national economy (2017). Odesa: IPREED NAN Ukrayiny. 564 p.

James, P. (2001), Toward sustainable bussines, in: Charter M., Tischner U. (eds), Sheffield

Kupalova, G. (2008). The theory of economic analysis: a textbook // K.: Knowledge. 639 p.

Law of Ukraine "On Innovative Activities". (2002). No. 40-IV 04.07.2002. Verkhovna Rada of Ukraine Information dated 06.09.2002. No. 36. Art. 266. [10 5 2019].

Nikishina, O. V., Zarudna, O. P. (2018). Globalization of commodity markets: theoretical and applied aspects // Economy of the food industry. T.10 (2): 9-21.

Nikishina, O.V. Bibikova, N.O. (2018). Formation and development of regional servicing cooperatives in the grain market: an integration approach. Odessa: IREPR NAS of Ukraine. 230 p.

Official site of the State Statistics Service of Ukraine. (2018). http://www.ukrstat.gov.ua [01 $072019]$.

Organisation for Economic Co-operation and Development. (2011). Regions and Innovation Policy // OECD Reviews of Regional Innovation. OECD Publishing. 319 p.

Organisation for Economic Co-operation and Development. (2015). The Innovation Imperative // Contributing to Productivity, Growth and Well-Being. OECD : Publishing Paris. 268 c.

Oslo, M. (2005). The Measurment of Scientific and Technological Activities: Proposed Guidelines for Collecting and Interpreting Technological Innovation Data // Organisation for Economic Co-operation and Development. $92 \mathrm{p}$.

Prahalad, K., Krishnan, M. (2011). The space of business innovation: Creating value with the consumer [trans. from the English.] // M.: Alpina Publishers: Yurayt Publishing House. 258 p.

Prokopenko, O. M. (Eds.). (2018). Environment of Ukraine Statistical collection. K .: State Statistics Service of Ukraine. 225 p.

Ryszko, A. (2016), Interorganizational Cooperation, Knowledge Sharing, and Technological Eco-Innovation: the Role of Proactive Environmental Strategy // Empirical Evidence from Poland, "Pol. J. Environ. Stud." Vol. 25 No. 2, p. 753-764

Schumpeter, J. (2007). The theory of economic development // Capitalism, socialism, democracy. M.: Exmo. 864 p.

Sharma, S., Vredenburg, H. (1998), Proactive corporate environmental strategy and the development of competitively valuable organizational capabilities // Strategy Management Journal. No. 19(8), p. 729 


\title{
Ecologization of the Innovative Development of Regions on the Principles of Glocalization. Olena Hetman, Olga Iermakova, Oleksandr Laiko, Oksana Nikisyna
}

Socio-economic development of the Ukrainian Black Sea region: challenges and opportunities. (2016). Odesa: IPREED NAN Ukrayiny. 810 p.

Yakovets, Y. (2011). Mythic innovations of the XXI century // Intern. Inst. P. Sorokina-N. Kondratiev. M.: ZAO // Publishing House Economics. 444 p.

\section{NOVATORIŠKOS REGIONŲ PLĖTROS EKOLOGIZAVIMAS GLOKALIZACIJOS PRINCIPUOSE}

\author{
*Olena Hetman, Olga Iermakova, Oleksandr Laiko, Oksana Nikishyna \\ Ukrainos nacionalinès moksly akademijos rinkos problemu ir ekonominiu ekologiniu tyrimu \\ institutas, Odesa, Ukraina
}

Gauta 201908 11, priimta 20190920

Šalies ekonominės politikos sėkmė priklauso nuo sėkmingo globalių pasaulio tendencijų ir nacionalinių / regioninių ekonominès plètros ypatumų derinio. Igyvendinant glokalizacijos principus ị regionų inovacijų politiką, galima ịveikti ribotą vietos požiūrị ir neigiamas globalias apraiškas, taip sukuriant unikalų, visame pasaulyje konkurencingą novatorišką produktą. Inovacijų srityje glokalizacijos procesai pasireiškia vietos inovacinio vystymosi veiksnių, ypač unikalaus inovacijų aplinkos, žmogiškojo ir socialinio kapitalo, papildomumu su globaliais inovacijų plètros veiksniais. Siūlome apsvarstyti regiono inovatyvios plètros ekologizacijos procesus kaip rinkos glokalizacijos procesų katalizatorių, kuris skatins darnią regiono ekonomikos plètrą. Šio darbo tikslas yra ištirti mokslinius inovacijų raidos ekologizacijos metodus, kurie nulems glocalizacijos procesų kryptị, ypatumus ir pobūdị ir bus šiuolaikinis jų greitintuvas. Tyrimo metodika yra požiūrių i inovacijų kūrimo, kūrimo ir diegimo inovacijų, susijusių su naujais produktais, technologijomis, metodais, gamybos organizavimo forma ir kt. Susisteminimas, kuris tiesiogiai ar netiesiogiai prisideda prie mažinimo žalingą gamybos ir vartojimo poveiki aplinkai ir aplinkosaugos problemų sprendimą. Tyrimo rezultatai. Galutinis regiono inovacijų veiklos ekologizacijos rezultatas yra teigiamas socialinis, ekologinis ir ekonominis poveikis, užtikrinantis subalansuotą darnų regiono ir visos valstybès vystymąsi. Taigi šiuolaikinis ekonominių procesų glokalizacijos spartintuvas yra inovacijų plètros ekologizavimas, kurio pobūdis yra paskatas savarankiškai tobulèti, daugintis, kurti inovatyvias idejjas, gaminti naujas technologijas, prekes ir paslaugas, užtikrinant pusiausvyrą. regiono ir visos šalies socialinį, ekologinị ir ekonominị potencialą, lemianti glokalizacijos procesų kryptį, ypatumus ir pobūdị.

Raktiniai žodžiai: novatoriškos plètros ekologizavimas, glokalizavimas.

JEL kodai: O10, Q50.

* Autorius pasiteirauti 